\title{
The role of social movements in the 'second incorporation' of popular sectors in Bolivia and Argentina
}

\author{
El papel de los movimientos sociales en la "segunda \\ incorporación" de sectores populares en Bolivia y Argentina
}

Enrico Padoan (iD)

Scuola Normale Superiore, Italia

enrico.padoan1@sns.it

Received / Recibido: 03/09/2019 Accepted / Aceptado: 05/06/2020

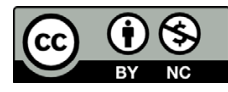

ABSTRACT

Latin American 'Pink Tide' has been functionally interpreted as a 'second wave of incorporation' of the popular sectors in the polity domain after their 'disincorporation' and/or exclusion by authoritarian regimes and/or neoliberal reforms. This contribution proposes a comparative analysis of the roles played by social movements in Bolivian and Argentinean "second incorporations", by relying on fifty in-depth interviews with partisan and movement leaders in both countries, in order to assess the different characteristics and consequences of the processes of "second incorporation" in the two countries. The paper argues that the extent to which such actors provide an encompassing representation of 'excluded sectors' is key to understand how different forms of political incorporation shaped different 'social blocs' either supporting or contrasting progressive political projects in power, and eventually created the conditions, in the medium term, for the electoral rise of right-wing opponents.

Keywords: Political incorporation; Latin American left turn; social movements; trade unions; populism.

\section{RESUMEN}

Destacados autores han argumentado que el "giro a la izquierda" en América Latina tuvo la función histórica de incorporar políticamente a amplios sectores populares que carecían de estructuras de representación de sus intereses. Este artículo propone una comparación entre los procesos de "incorporación a través de movimientos sociales" en Bolivia y Argentina, utilizando evidencias cualitativas (procedentes de cincuenta entrevistas en profundidad, recolectadas en marzo-mayo 2017, con actores políticos y sociales de los dos países) para poner en relieve las diferentes características y consecuencias de los dos procesos de "segunda incorporación". El artículo muestra que el nivel de representatividad de los movimientos sociales que se encargaron de incorporar a los sectores excluidos resulta clave para entender cómo los procesos de incorporación en Bolivia y Argentina articularon distintos bloques sociales (a favor y en contra de los gobiernos de izquierda) y, por ende, contribuyeron de forma distinta a la consolidación, en el mediano plazo, de proyectos políticos opositores.

Palabras claves: incorporación; giro a la izquierda; movimientos sociales; sindicatos; populismo. 


\section{INTRODUCTION. 'SECOND POLITICAL INCORPORATIONS' IN LATIN AMERICA DURING THE PINK TIDE - AND THEIR CONSEQUENCES}

In their classic work, Ruth and David Collier (1991) defined the concept of 'workingclass incorporation' as 'the first sustained and at least partially successful attempt by the state to legitimate and shape an institutionalized labor movement' (p. 783). The ways in which such incorporation occurred (either through state structures or through mass-party organisations) produced different and long-lasting effects on the conformation of the party systems, on party-society relations and on socio-economic models of development. Federico Rossi $(2015 ; 2018)$ forcefully argued that Latin American 'Pink Tide' can be functionally interpreted as a 'second wave of incorporation' of the popular sectors in the polity domain after their 'disincorporation' and/or exclusion by authoritarian regimes and/ or neoliberal reforms. According to Rossi, in such 'second wave', the social actors that acted as the main representative of those sectors looking for incorporation were territory-based social movements, instead of function- or class-based trade unions, as it occurred in the 'first wave'.

The hypothesis animating this research is that the extent to which such actors provide an encompassing representation of 'excluded sectors' is key to understand how different forms of political incorporation shaped different 'social blocs' either supporting or contrasting progressive political projects in Latin America, and eventually created the conditions, in the medium term, for the electoral rise of right-wing opponents. This contribution proposes a comparative analysis of the Bolivian and Argentinean 'second incorporations through the movements', by relying on primary data collected through fiftyfive in-depth interviews, conducted in March-June 2017 in the four Bolivian major cities - La Paz, El Alto, Cochabamba, Santa Cruz - as well as Buenos Aires.

Castillo and Barrenechea (2016) define 'political incorporation' as 'a process through which a previously excluded actor acquires policy benefits and (new forms of) representation in the state'. Such 'new forms of political representation' can take three different forms: partisan (through a political party), corporatist ('a form of interest representation in which organized interests that are officially recognized have direct access to voice or decisionmaking spaces within the state', as Castillo and Barrenechea [2016, p. 7] put it) and personalistic (which stands for 'non-institutional' representation of the excluded actor by a charismatic leader). I rely on such definition for the purposes of this article, with one (major) difference: I argue that we should refer to excluded sectors, instead of actors. The former (excluded sectors) are constituencies lacking political representation and thus lacking political resources to defend their interests, vis-à-vis better-organised constituencies. The latter (excluded actors) are organisations claiming to represent some excluded sectors and looking for entering the polity domain. The concrete ability or capacity, by excluded actors, of positioning themselves as encompassing representatives of excluded sectors depend on organisational strength, but also on some forms of political recognition ('from above') of their status of 'legitimated representative' of those sectors.

This article first discusses how 'second incorporations' in Latin America took different forms, and then analyses, through primary and secondary sources, Bolivian and Argentine 'second incorporations', in which social movements played key (albeit different) roles. In Bolivia, encompassing well-organised movements provided the resources to 'incorporate' the peasantry and other constituencies mostly occupied in the informal economy. The gradual loss of political initiative constrained the movements to play a (still relevant) role of intermediation between State and society, with some opaque consequences that reduced governmental support, particularly amongst middle-upper classes and salaried workers in formal economy. In Argentina, 'incorporating' movements were much less 
encompassing than Bolivian ones, and tended to rely on particularistic arrangements with Peronist-Kirchnerist political machinery. Such peculiar form of incorporation made right-wing arguments attacking 'welfarist' measures increasingly resonant even amongst growing segments of the popular sectors, thus benefitting Mauricio Macri's candidacy in view of 2015 elections.

\section{VARIETIES OF 'SECOND INCORPORATIONS' IN LATIN AMERICA}

Roberts (2014) showed how neoliberal reforms during the phase of the Washington Consensus produced major social turmoil in those countries (such as Argentina, Uruguay, Brazil, Bolivia and Venezuela) based on a 'state-centered matrix' (Filgueira et al., 2012), as a heritage of the ISI ${ }^{1}$ phase of development. Roberts showed that where left-of-centre or labour-based parties (Levitsky, 2003) took the responsibility of implementing marketfriendly reforms, new 'populist' challengers - such as Hugo Chávez, Néstor Kirchner and Evo Morales, but also Rafael Correa - exploited the window of opportunity opened by severe economic crises and occupied the political vacuum on the Left. In contrast, in Uruguay or Brazil - where neoliberal reforms were implemented by conservative actors - existing social-democratic alternatives strengthened.

In most countries where populist challengers aroused, we observed the emergence of protest cycles animated by contentious, anti-neoliberal social movements anticipating changes at the political level (Silva, 2009). Populist challengers developed different kinds of relationship with such movements, also because of the varying strengths achieved by the latter in different contexts. In Ecuador, when Correa's candidacy began attracting widespread support, indigenous movements, environmental organisations and radical unions, which for a while had formed a powerful alliance network, were in evident decline, mainly due to divisions and loss of social support following their support to the unpopular Gutiérrez government (Van Cott, 2005; Becker, 2013). In Venezuela, social protests against neoliberal reforms during the nineties appeared extremely fragmented, across sectorial, territorial and class divides (López Maya, 1999; Levine, 2002; García-Guadilla, 2007). While Correa's governmental style has been labelled 'technocratic' (Becker, 2013) and increasingly alienated the support of the movements (De La Torre, 2013), Hugo Chávez notoriously spent many energies and public resources to create and consolidate his own organised support amongst Venezuelan popular sectors (Wilpert, 2007; Ellner, 2011). Said this, nor in Ecuador, nor in Venezuela, autonomous movements played any relevant political or organisational role within Correa's and Chávez's populist projects, at least during their early phase.

Things went much differently in Bolivia and Argentina. Morales' party MAS-IPSP has been aptly categorised as a 'movement-based party' (Van Cott, 2005; Anria, 2014), a sort of 'electoral arm' of three major peasant social movements (the so-called trillizas, 'triplets') and of cocaleros (coca leaf croppers) (Zuazo, 2008). The MAS-IPSP is little more than an 'electoral brand' (BO5; BO21), without autonomous organisational structures, which instead overlap with those of the 'founding movements' and with other urban, indigenous or sectorial organisations that joined the MAS-IPSP throughout the years and that have the control, at least formally, and with some exceptions, of the candidate selection process (Anria, 2014). The trillizas, particularly since the nineties, were able to lead and consolidate a wide alliance network of indigenous, rural and urban movements (Yashar, 2005; Silva, 2009) that animated a long and successful anti-neoliberal protest-cycle paving the way for the landslide victory of Evo Morales in the 2005 presidential elections. Despite the relevance of personalistic incorporation of peasant and indigenous people from Bolivian Highlands, through the own figure of Morales, partisan and corporatist forms of incorporations were

1 Industrialisation through the Substitution of Importations. 
preeminent. Due to the peculiar organisational structure of the MAS-IPSP, such forms of incorporations were closely intertwined. In addition, and crucially, such a corporatist incorporation occurred through highly encompassing and deep-rooted social movements and organisations.

The Argentine contentious cycle instead began mounting in the mid-nineties, when Menem's neoliberal reforms provoked severe social and economic negative effects. Unemployed workers, first in remote Argentine provinces affected by privatisations and job reduction in the public sector, and then in Buenos Aires Province, made use of extensive road-blockages (piquetes) to force the state to distribute conditional subsidies (planes). The piquetero movement evolved as a complex and fragmented constellation of groups, movements and organisations, located in different neighbourhoods, municipalities and provinces, and highly heterogeneous in terms of ideological inspirations, spamming from Trotskyist and revolutionary organisations - often linked to small radical Left parties - to left-wing Peronist, Catholic, and anti-Peronist centre-Left movements (Pereyra \& Svampa, 2003; Boyanovsky, 2010). Piquetero movements dominated Argentine 'street politics' under De La Rúa (1999-2001) and Duhalde (2002-2003) presidencies by showing very high mobilising capacity and, consequently, strong blackmail potential to force national and provincial governments to respond through targeted and discretionary social schemes (Rossi, 2015).

In 2002 Néstor Kirchner, backed by Duhalde's Peronist electoral machine, won the presidential elections with an extremely weak popular support (22 percent of the voters). Once in office, Kirchner immediately began building his own social and political base of support, through a leftist-populist strategy, the so-called Transversalidad (Ostiguy \& Schneider, 2018). He assumed courageous positions against foreign creditors and the military, pushed for redistributive measures through the governmental support towards unions' demands (Etchemendy \& Collier, 2007) and gradually 'freed' himself from Duhalde's political control. Crucially, Kirchner began a sort of 'selective incorporation' of the piquetero's movement, through the concession of governmental (secondary) positions and the access to (limited) public resources to those organisations that proved to be pragmatic enough to dialogue with the Peronist machinery (Rossi, 2015). By doing this, Kirchner steadily constrained more radical, ideologised or less pragmatic groups to political isolation and, at the same time, he was able to achieve 'governability' through the appeasement of most piquetero's movements, which provided both militancy and 'social peace'. Thus, as I will further detail below, the 'political incorporation' of excluded sectors under Kirchnerism occurred mostly through corporatist (and particularistic) arrangements with fragmented and non-encompassing social actors, as well as through partisan representation, nurtured by the notorious identification of popular sectors with Peronism (Levitsky, 2003; Lupu et al., 2018).

\section{BOLIVIAN ‘SECOND INCORPORATION'. ENCOMPASSING SOCIAL MOVEMENTS AND CORPORATIST ARRANGEMENTS}

Bolivian trillizas are extremely deep-rooted organizations enrolling hundreds of thousands of small (and very small, more often than not) landowners throughout the country (García Linera et al., 2004). This made them perfectly fit for the task of developing an 'electoral arm' that was gradually joined by other social organisations, either territorybased (such as urban juntas de vecinos) or sectorial-based (such as guilds representing street vendors, self-employed informal workers, or mineworkers affiliated to cooperatives) of the hyper-organised Bolivia society (see Figure 1). One could think of the MAS-IPSP as a movement-based party that was dominated by some 'core' organisations (trillizas and cocaleros) and joined by a constellation of organisations, typically representing self- 
employed workers in the informal economy (Tassi et al., 2012), which obtained the right of participating in the processes of candidate selection and agenda setting through complex and informal bargaining with the rest of the actors belonging to the masista coalition. These 'non-core' organisations in some cases acted as veto players within the party and, since Morales' victory, within the government (Zegada \& Komadina, 2011).

To affirm that the MAS-IPSP is a movement-based party does not imply that it is movement-controlled. The own process of inclusion of organisations other than the trillizas and the cocaleros diminished the control of the 'core organisations' over their 'instrument' (García Yapur et al., 2014), while assigning to the party leadership (i.e., to Morales and his inner circle) a crucial mediatory role between potentially conflicting interests. Until the end of Morales' first presidential term (2009), the movements still retained a high capacity of influencing the political and strategic agenda of the MAS-IPSP in government (BO1; B09; BO21), particularly during the complex process leading to the elaboration of the new Constitution. Nevertheless, some changes in the role of the social movements became visible since the creation, in 2008, of the CONALCAM ('National Commission for Change'), a sort of umbrella group, for mobilising and electoral purposes, of pro-governmental movements and organisations (Mayorga, 2010): the 'government of the social movements' gradually became the 'government through the social movements'.

As several interviewees put it, after the winning in 2009 general elections, the 'organic' movements firmly expected that 'their turn' for 'receiving dividends' had come (BO5; BO13; BO20; B021). The trillizas and the other 'non-core' organisations gradually became a sort of intermediaries between the government of the new Plurinational State and rural and urban communities to guarantee the access to public resources (mainly in terms of infrastructural works and productive investments) to the latter, while assuring electoral support to the former.

Figure 1. Percentage of citizens declaring to be affiliated to political parties, trade unions and civic organisations in South American countries

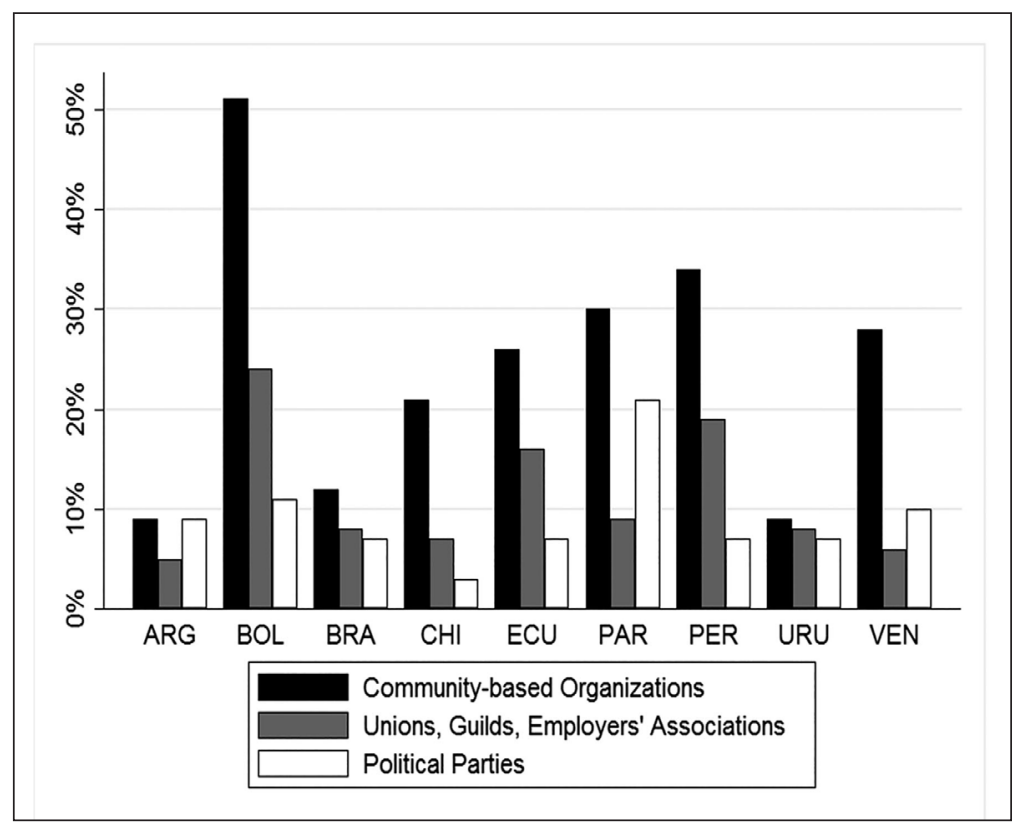

Source: Author's Elaboration from 2012 LAPOP Survey 
In the first Morales' cabinet (2005), Ministries with a 'social movement background' were $69 \%$ (10 out of 16). Two years later, this percentage fell to $44 \%$, and, nine years later, to $15 \%$ (Oikonomakis and Espinoza, 2014: 19). Such loss of political influence in strategic decisions was accompanied by the development of a kind of 'corporatist' system, which assured to the encompassing movements joining the proceso de cambio (each of them representing quite specific sector- and territory-based constituencies of the complex Bolivian society) an effective 'voice' in the political exchanges internal to the governmental socio-political coalition. Morales and his government thus began acting as a 'chamber of compensation' for the different popular demands coming from the organisations forming part of the masista coalition. In the words of the leader of the CSCIOB:

\footnotetext{
'In the past, who cared about us? To approve a bill, a project, a decree, who dialogued with us? Nobody. [...] The government now goes to hear even the furthest Bolivian community; it receives many proposals. For instance, yesterday, I had a meeting with the President. I advanced, political, productive claims. And I am sure that all the social organisations do this. Through these reunions, the 'Patriotic Agenda' was drafted. It is not true that the 'Patriotic Agenda' comes from the government. This is the rhetoric of the Right. They want to divide the government from us'.
}

Such system of interest aggregation contributed to define a peculiar political economy of masista Bolivia. As it has been explicitly theorised by Minister of Economy Arce Catacora (2015), the public participation in extractive sectors, generating high revenues but little employment, would provide public resources to be reinvested in social policies (such as several, and highly popular, conditional cash transfers) and to foster productivity in labourintensive sectors, in an attempt of 'formalising' Bolivian economy. Nevertheless, income redistribution, infrastructural works and stimulus towards export-oriented agriculture have been accompanied by the 'protection' of informal sectors and the creation of an 'indigenous bourgeoisie' with strong influence within the MAS-IPSP (Crabtree \& Chaplin, 2013), in detriment of labour-intensive secondary sectors (McNelly, 2019a). Albeit initially included as 'full members' within the masista coalition, indigenous movements have gradually been either controlled by the government or pushed to the opposition camp, because of the governmental extractivist agenda (see Paz, 2011; B01). In a similar vein, the $\mathrm{COB}$, i.e. the historical Bolivian peak union confederation, traditionally dominated by salaried mineworkers, has seen its role reduced to subordinated ally, with little influence on governmental economic strategies, uncapable to recuperate its traditional political weight - also because of the ongoing diminution of the size of formal salaried sectors and prey of (often successful) attempts of co-optation by the government (McNelly, 2019b).

The support of the trillizas to such socioeconomic model of development is well captured by this extract from my interview with CSUTCB's leader in 2017:

\footnotetext{
'Our goals are freedom and social justice; thus we do not fight for small things [...]We do not care about doble aguinaldo [the compulsory 'second bonus' introduced by Morales for formal, salaried workers], we don't care about the salary, because the salary could end, a job could end, a mine could end, but our work will never end. Therefore, our claims, as peasants, have more to do with productive issues, something that we were not allowed to discuss with the neoliberal governments. Now we can talk about a lot, a lot, a lot of projects and programmes related with production, irrigation, roads, genetic improvements that we are discussing now...' (B04).
}

Instead, many interviewees from the $\mathrm{COB}$ (BO3; $\mathrm{B} 012 ; \mathrm{BO} 22)$ and from indigenous and environmental organisations (BO20; $\mathrm{BO} 25$; $\mathrm{BO} 2$ ) precisely contest such evolution that brought, as negative externalities: conflicts between the state and indigenous movements, land concentration and benefits for exploitative export-oriented monocultures (and much less so for microfundistas), little (if any) improvement or defense of workers' labour rights to appease foreign investors in industrial sectors (McNelly, 2019b), economic growth 
concentrated in extractive, financial and construction sectors (and poor 'trickle-down' effects on formal labour-intensive sectors, also damaged by competition from 'informal' economy: Tassi et al., 2012; BO22; BO27). Furthermore, prebendal tendencies and cooptation of both rural and urban movements supporting the masista project contributed to alienate much of the support of urban middle-class that Morales' governments initially enjoyed (B05; B016). At the same time, social rootedness and high representativeness of Bolivian peasant movements encapsulated the support for the MAS-IPSP by vast constituencies (García Yapur et al., 2014) and decisively contributed to impose a new hegemonic discourse, in which 'sovereignty', defense of indigenous people, and social justice became valence issues in the public political sphere.

Far from being mere speculations, much of these considerations may help to shed light on the chaotic and still unclear social and political turmoil in the aftermath of the contested presidential elections of October 2019. Without addressing any debates about the role of the military and the police, or about the accusations of electoral frauds, it is a fact that a broad antimasista political and social coalition was created, spamming from conservative elites to indigenous organisations, with urban middle-class sectors as its backbone, attacking the MAS-IPSP's 'system of power'. Masistas 'core' organisations kept their loyalty towards Morales. Nevertheless, some 'non-core' masistas organisations, whose relationship with the MAS-IPSP had always been much more instrumental, either 'switched' to the opposition (such as the cooperativistas mineros) or, while criticising the right-wing opposition, suggested the 'exit' option to Morales (this was the early position of the $\mathrm{COB}$ )' The defections of groups that had fallen outside the masista system of political exchanges may have been crucial to determine the (temporary?) defeat of the proceso de cambio.

\section{ARGENTINE 'SECOND INCORPORATION'. FRAGMENTED SOCIAL MOVEMENTS AND PARTICULARISTIC NEGOTIATIONS}

Kirchner initially appeared to be a weak president in an out-of-control country: despite a timid economic recovery and the launch, by Duhalde's presidency, of quite extensive social schemes to cope with extreme poverty (such as the PJJHD, 'Unemployed Households Plan'), social unrest was still erupting. Kirchner's Transversalidad allowed the new President to acquire political autonomy from Duhalde and to gradually build a vast social and political coalition of support. The inclusion of 'pragmatic' piqueteros into his coalition, as well as ongoing economic growth, decisively contributed to reduce social conflict (Rocca Rivarola, 2006; Rossi, 2015).

'Second incorporation' in Argentina was pursued through the inclusion of piqueteros leaders in the so-called 'Piquetero Cabinet', linked to the Presidential Secretariat and to other functionaries belonging to other Ministries, to deal with the piquetero claims in a conciliatory way (Boyanovsky, 2010; Natalucci, 2011; AR7; AR10; AR13). Kirchner's strategy offered to piqueteros groups an unprecedented opportunity (AR7; AR13) to gain a stable access to the distribution of funds for the communitarian projects financed by the PJJHD and by other schemes that Kirchner created later through the Ministry of Social Development (Rossi, 2015).

However, the amount of funds and planes directly administrated by these organisations was not particularly high, in order not to irritate the Justicialist Party machine (Boyanovsky, 2010; AR4; AR13). In fact, Argentine 'second incorporation' was part of the broader process of coalition building successfully pursued by Néstor Kirchner during his presidential term.

2 For a broad reconstruction of the Bolivian events, see Molina (2019). 
Such coalition included both the (Peronist) main peak union confederation (the CGT, 'General Confederation of Work') and the left-wing union confederation CTA ('Argentine Workers' Central', with strong links to piquetero's milieu: AR4; AR13). Argentine 'second incorporation' was parallel to a sort of a 're-incorporation' of the salaried working-class, through both the governmental support of the CGT in negotiations vis-à-vis the employers (Etchemendy \& Collier, 2007) and economic policies aiming at state intervention in the market to foster job creation and the 'formalisation' of the productive system (Marticorena, 2014; Kulfas, 2016).

The role of unions, as well as of the 'formalisation' of economy to deal with unemployment, was thus much more central in Kirchnerist Argentina than in masista Bolivia (AR8). Furthermore, another crucial part of the Kirchnerist coalition (and of the process of 'second incorporation') was the Justicialist Party, which was gradually 'reconquered' by Kirchner (Arzadún, 2013). The high public opinion support enjoyed by the President convinced several major Peronist figures to gradually abandon Duhalde's factions (as certified in 2005 legislative elections) and to offer to Kirchner the electoral base that the Peronist machine continued to assure, thanks to enduring party identification amongst popular sectors (Lupu et al., 2018) and to its social rootedness, often reproduced by traditional clientelistic forms (Auyero, 2001; Brusco et al., 2004).

In sum, under Néstor Kirchner's presidency, we witnessed both the 're-incorporation' of the organised working-class and a 'second incorporation' involving, in terms of 'policy benefits', the coexistence of job creation with highly discretionary and particularistic social schemes that were distributed following political logics and managed by PJ's local intermediaries (the punteros: e.g., Auyero 2001; Levitsky, 2003) and piqueteros leaders, in reciprocal competition. Depicting the relationship between the Kirchnerist state and piqueteros groups as 'clientelistic' would be quite misleading, as it would overlook the 'empowering' dimension of piqueteros' phenomenon (Garay, 2007; Rossi, 2015; AR7; AR10; AR12), in contrast to the asymmetrical exchanges between punteros and voters. Nevertheless, Néstor Kirchner's 'second incorporation through the movements' aimed more at achieving 'social peace' than at assuring electoral support, which was mostly guaranteed by partisan incorporation of 'excluded sectors' and by unemployment reduction through formal salaried jobs and economic recovery.

Under the presidential terms of Cristina Fernández de Kirchner (CFK), the process of 'second incorporation' took different forms. On the one hand, CFK, as a reaction to a difficult political conjuncture (AR8; Zarazaga, 2012), implemented a truly universalist (and not discretionary) pro-poor social scheme, the 'Universal Child Allowances' (AUH). Nevertheless, she maintained a sort of 'division of labour' between such universal social scheme and other, targeted programmes to be used discretionarily for political purposes (Zarazaga, 2012). Crucially, CFK pursued the creation of her own organised base of support symbolised by the consolidation of Left-Peronist organisation La Cámpora, widely favoured in the distribution of governmental charges - instead of relying on the coalition patiently articulated by her predecessor (Padoan, 2020). By doing so, she alienated the support of important PJ's factions and of the CGT, which was, on the contrary, reclaiming much more political influence within the Peronist-Kirchnerist processes of candidate selection and policy-making (AR1; AR8).

This evolution led, in view of the 2015 presidential elections, to the rupture between the Kirchnerist candidate Daniel Scioli and the coalition of Peronist unions and Peronist dissidents led by Sergio Massa, which resulted decisive for the defeat of Scioli against rightwing neoliberal Mauricio Macri. Such rupture has been interpreted by Torre (2017), in a way that perfectly matches the argument of this article, as structurally determined. While the poorest sectors and the movements' milieu remained loyal to Kirchnerism, relevant sectors 
of the salaried working-class - increasingly irritated by social policies schemes following political logics and targeting 'underserving' constituencies - switched their vote towards Massa's project. Only in view of the 2019 presidential elections Kirchnerism and Peronism rejoined their forces in a renewed and successful alliance, bringing the presidential ticket Alberto Fernández-Cristina Fernández back to the Casa Rosada.

\section{CONCLUDING REMARKS}

Analyses of socio-structural determinants of electoral choices in the aftermath of the 'Pink Tide' offer promising, and still insufficiently explored, research avenues (see Berens \& Kemmerling, 2019). From a normative point of view, such analyses could shed more light on the deficiencies of the socioeconomic models (and on their long-lasting, multiple heritages) implemented by left-wing populist experiences, by following the broad literature (e.g., Gudynas, 2009; Svampa, 2015; Brand et al., 2016) over the consequences of such forms of 'redistributive extractivism' that, in most cases, became an 'easier path' to avoid to challenge deeper structural bases of social inequality. In order to follow this research agenda, it is key to look at the cross-class (and possibly fragile) social alliances that each of these left-wing experiences crafted during their governmental experiences, through peculiar and different political economies.

This short article also calls for further comparative research exploring the role played by contentious social movements during the 'Pink Tide' (see Silva \& Rossi, 2018) and their relationship with institutional actors, as well as the consequences of such linkages. I would tentatively argue here that the gradual loss of autonomy suffered by Bolivian territorial movements made them similar, on this aspect, to their Venezuelan counterparts, and offered some arguments to right-wing oppositions. This did not occur to the same extent in the case of the PT in Brazil, where we observed a consistent tendency of "cartelization" (Katz \& Mair, 1995) by the party, which often resulted in quite tense movement-party relations - but also in the maintenance of a certain movements' autonomy (e.g., Samuels, 2004; Hunter, 2011).

In another key case, such as Chile, social movements prospered in a scenario marked by an evident separation between the social and the (highly technocratic) political sphere. Furthermore, in Chile we can observe the extreme weakness of associational structures stemming from popular sectors - a feature that marks a clear difference with other case studies addressed here, thus suggesting different comparisons. The 2011 Chilean wave of protests, articulated by university students, had its electoral crystallisation in the (ephemeral?) electoral achievements of the Frente Amplio (in a way echoing the trajectory of Podemos in Spain). The ongoing second wave has been dominated by what Aslanidis (2016, pp. 304-305) defines "populist social movements": "non-institutional collective mobilization which attributes currently suffered grievances to a society ultimately separated in two homogeneous and antagonistic groups, the overwhelming majority of 'pure People' versus the 'corrupt elite', and claims to speak on behalf of the former in demanding the restoration of political authority into their hands, as rightful sovereigns". The lack of credible political articulators and of effective organisational structures makes the contemporary Chilean scenario open to political contingency. 


\section{REFERENCES}

Anria, S. (2014). Social Movements, Parties, and the Left in Latin America: the Bolivian MAS (Movement Towards Socialism) in comparative perspective (Doctoral Dissertation). University of North Carolina, Chapel Hill.

Arce Catacora, L. (2015). El modelo económico social comunitario productivo boliviano. La Paz: Soipa.

Arzadún, D. (2013). Peronismo y Kirchnerismo. Guerra, muerte y resurrección. Buenos Aires: Agebe.

Aslanidis, P. (2016). Populist Social Movements of the Great Recession. Mobilization: An International Quarterly, 21(3), 301-321. https://doi.org/10.17813/1086-671X-20-3-301

Auyero, J. (2001). Las políticas de los pobres. Las prácticas clientelistas del peronismo. Buenos Aires: Manantial.

Becker, M. (2013). The Stormy Relations between Rafael Correa and Social Movements in Ecuador. Latin American Perspectives, 40(3), 43-62. https://doi.org/10.1177/0094582X13479305

Berens, S., \& Kemmerling, A. (2019). Labor Divides, Informality, and Regulation: The Public Opinion on Labor Law in Latin America. Journal of Politics in Latin America, 11(1), 23-48. https://doi.org/10.1177/1866802X19843362

Boyanovsky, C. (2010). El aluvión. Del Piquete al Gobierno: Los movimientos sociales y el Kirchnerismo. Buenos Aires: Sudamericana.

Brand, U., Dietz, K., \& Lang, M. (2016). Neo-Extractivism in Latin America. One Side of a New Phase of Global Capitalist Dynamics. Ciencia Política, 11(21), 125-159. https://doi.org/10.15446/cp.v11n21.57551

Brusco, V., Nazareno, M., \& Stokes, S. (2004). Vote Buying in Argentina. Latin American Research Review, 39(2), 66-88. https://doi.org/10.1353/lar.2004.0022

Castillo, I., \& Barrenechea, R. (2016). Political incorporation (in Latin America). The concept, the variations, and the cases. Documentos de Trabajo ICSO, 26/2016.

Collier, D., \& Collier, R. (1991). Shaping the Political Arena. New York: Princeton University Press.

Crabtree, J., \& Chaplin, A. (2013). Bolivia: Procesos de Cambio. La Paz: PIEB.

De La Torre, C. (2013). In the Name of the People: Democratization, Popular Organizations, and Populism in Venezuela, Bolivia, and Ecuador. European Review of Latin American and Caribbean Studies, 95(4), 27-48. https://doi.org/10.18352/erlacs.9229

Ellner, S. (2011). Venezuela's social-based democratic model: innovations and limitations. Journal of Latin American Studies, 43(3), 421-449. https://doi.org/10.1017/S0022216X11000757

Etchemendy, S., \& Collier, R. (2007). Down but not Out: Union Resurgence and Segmented Neocorporatism in Argentina (2003-2007). Politics and Society, 35(3), 363-401. https://doi.org/10.1177/0032329207304318

Filgueira, F., Reygadas, L., Luna, J.P., \& Alegre, P. (2012). Shallow States, Deep Inequalities, and the Limits of Conservative Modernization: The Politics and Policies of Incorporation in Latin America. In M. Blofield (Ed.), The Great Gap (pp. 245-277). University Park: Penn State University Press. 
Garay, C. (2007). Social Policy and Collective Action: Unemployed Workers, Community Associations and Protests in Argentina. Politics and Society, 35(2), 301-328. https://doi.org/10.1177/0032329207300392

García-Guadilla, M. (2007). Social Movements in a Polarized Setting: Myths of Venezuelan Civil Society. In S. Ellner, \& M. Tinkner Salas (Eds.), Venezuela: Hugo Chavez and the Decline of an Exceptional Democracy (pp. 140-154). Lanham: Rowman \& Littlefield.

García Linera, Á., Chávez, M., \& Costas, P. (2004). Sociología de los Movimientos Sociales en Bolivia. La Paz: Editorial Plural.

García Yapur, F., García Orellana, A., \& Soliz, M. (2014). 'MAS legalmente, IPSP legítimamente'. Ciudadanía y devenir Estado de los campesinos indígenas en Bolivia. La Paz: PIEB.

Gudynas, E. (2009). Diez tesis urgentes sobre el nuevo extractivismo. In J. Schuldt (Ed.), Extractivismo, política y sociedad (pp. 187-225). Quito: CAAP.

Hunter, W. (2011). Brazil: The PT in Power. In S. Levitsky, \& K. Roberts (Eds.), The Resurgence of the Latin American Left (pp. 306-324). Baltimore: The John Hopkins University Press.

Katz, R., \& Mair, P. (1995). Changing Models of Party Organization and Party Democracy: The Emergence of the Cartel Party. Party Politics, 1(1), 5-28. https://doi.org/10.1177/1354068895001001001

Kulfas, M. (2016). Los tres Kirchnerismos. Una historia de la economía argentina 2003-2015. Buenos Aires: Siglo Veintiuno.

Levine, D. (2002). The Decline and Fall of Democracy in Venezuela: Ten Theses. Bulletin of Latin American Research, 23(2), 248-269. https://doi.org/10.1111/1470-9856.00042

Levitsky, S. (2003). Transforming Labor-Based Parties in Latin America: Argentine Peronism in Comparative Perspective. Cambridge: Cambridge University Press.

López Maya, M. (1999). Venezuela después del Caracazo: Formas de la protesta en un contexto desinstitucionalizado. Kellogg Institute Working Paper \# 287.

Lupu, N., Oliveros, V., \& Schiumerini, L. (Eds.) (2018). Campaign and Voters in Developing Democracies. Cambridge: Cambridge University Press.

Marticorena, C. (2014). Trabajo y negociación colectiva. Los trabajadores en la industria argentina, de los noventa a la posconvertibilidad. Buenos Aires: ImagoMundi.

Mayorga, F. (2010). Antinomías. El azaroso camino de la reforma política. Cochabamba: CESU.

McNelly, A. (2019a). Neostructuralism and Its Class Character in the Political Economy of Bolivia Under Evo Morales. New Political Economy, advanced online publication. https://doi.org/10.1080/13563467.2019.1598962

McNelly, A. (2019b). Labour Bureaucracy and Labour Officialdom in Evo Morales's Bolivia. Development and Change, 50(4), 896-922. https://doi.org/10.1111/dech.12453

Molina, F. (2019). Bolivia: ¿golpe o (contra)revolución? Nueva Sociedad. Retrieved from https://www.nuso.org/articulo/bolivia-golpe-o-contrarevolucion/

Natalucci, A. (2011). Entre la movilización y la institucionalización. Los dilemas de los movimientos sociales (Argentina, 2001-2010). Polis, 10(1), 193-219.

http://doi.org/10.4067/S0718-65682011000100012

Oikonomakis, L., \& Espinoza, F. (2014). Bolivia's MAS and its actual relation with the movements that brought it to state power. In R. Stahler Sholk, M. Becker, \& H. Vanden 
(Eds.), Rethinking Latin American Social Movements: Radical Action from Below (pp. 285306). Lanham: Rowman \& Littlefield Publishers.

Ostiguy, P., \& Schneider, A. (2018). The Politics of Incorporation: Party Systems, Political Leaders and the State in Argentina and Brazil. In E. Silva, \& F. Rossi (Eds.), Reshaping the Political Arena in Latin America: From Resisting Neoliberalism to the Second Incorporation (pp. 275-308). Pittsburgh: Pittsburgh University Press.

Padoan, E. (2020). Anti-Neoliberal Populisms in Comparative Perspective. London: Routledge.

Paz, S. (2011). La marcha indígena del 'TIPNIS' en Bolivia y su relación con los modelos extractivos de América del Sur. GEOgraphia, 13(26), 7-36.

https://doi.org/10.22409/GEOgraphia2011.v13i26.a13623

Pereyra, S., \& Svampa, M. (2003). Entre la ruta y el barrio. La experiencia de las organizaciones piqueteras. Buenos Aires: Biblos.

Roberts, K. (2014). Changing Course in Latin America: Party Systems in the Neoliberal Era. Cambridge: Cambridge University Press.

Rocca Rivarola, D. (2006). La Matanza: avatares de la continuidad asegurada. Peronismo, partidos opositores y organizaciones piqueteras. In I. Cheresky (Ed.), La política después de los partidos (pp. 133-172). Buenos Aires: Prometeo.

Rossi, F. (2015). The Second Wave of Incorporation in Latin America: A Conceptualization of the Quest for Inclusion Applied to Argentina. Latin American Politics and Society, 57(1), 1-28. https://doi.org/10.1111/j.1548-2456.2015.00256.x

Rossi, F. (2018). The Poor's Struggle for Political Incorporation: The Piquetero Movement in Argentina. Cambridge: Cambridge University Press.

Samuels, D. (2004). From Socialism to Social Democracy. Party Organization and the Transformation of the Workers' Party in Brazil. Comparative Political Studies, 37(9), 9991024. https://doi.org/10.1177/0010414004268856

Silva, E. (2009). Challenging Neoliberalism in Latin America. Cambridge: Cambridge University Press.

Silva, E., \& Rossi, F. (Eds.). (2018). Reshaping the Political Arena in Latin America: From Resisting Neoliberalism to the Second Incorporation. Pittsburgh: University of Pittsburgh Press.

Svampa, M. (2015). Commodities Consensus: Neoextractivism and Enclosure of the Commons in Latin America. South Atlantic Quarterly, 114(1), 65-82. https://doi.org/10.1215/00382876-2831290

Tassi, N., Medeiros, C., Rodríguez, A., \& Ferrufino, G. (2012). 'Hacer plata sin plata'. El desborde de los comerciantes populares en Bolivia. La Paz: PIEB.

Torre, J.C. (2017). Los huérfanos de la política de partidos revisited. Panama Revista, 10(8). Retrieved from http://www.panamarevista.com/los-huerfanos-de-la-politica-de-partidos-revisited/

Van Cott, D. (2005). From Movements to Parties in Latin America: The Evolution of Ethnic Politics. New York: Cambridge University Press.

Wilpert, G. (2007). Changing Venezuela by Taking Power: The History and Policies of the Chavez Government. London: Verso.

Yashar, D. (2005). Contesting Citizenship in Latin America: The Rise of Indigenous Movements and the Postliberal Challenge. Cambridge: Cambridge University Press. 
Zarazaga, R. (2012). Los Programas de Transferencias Monetarias Condicionadas en Argentina. Análisis sobre el alcance, las condicionalidades y el clientelismo en la Asignación Universal por Hijo y el Programa Argentina Trabaja. Documentos de Trabajo \# 13, CIAS.

Zegada, M., \& Komadina, J. (2011). El espejo de la sociedad. Poder y representación en Bolivia. La Paz: Plural Editores.

Zuazo, M. (2008). ¿Cómo nació el MAS? La ruralización de la política en Bolivia. La Paz: Friedrich Ebert Stiftung.

\section{BIOGRAPHICAL NOTES}

Enrico Padoan (PhD, Pontificia Universidad Católica de Chile) is a post-doc researcher at the Faculty of Social and Political Sciences, Scuola Normale Superiore, Florence. His main research interests focus on populism, party organization, labour politics, and the relationship between populism and culture. He has recently published Anti-Neoliberal Populisms in Comparative Perspective (Routledge). 
